\title{
Duodenal Infusion of Glucose Decreases Milk Fat Production in Grass Silage-Fed Dairy Cows
}

\author{
S. Rigout, ${ }^{* 1}$ S. Lemosquet, ${ }^{*}$ A. Bach, $\dagger$ \\ J. W. Blum, $\ddagger$ and H. Rulquin* \\ *Unité Mixte de Recherches Production du Lait, \\ Institut National de Recherche Agronomique, \\ 35590 Saint-Gilles, France \\ †Agribrands Europe San Juan 189 \\ Barcelona, Spain \\ ‡Division of Animal Nutrition and Physiology, \\ Institute of Animal Genetics, Nutrition and Housing, University of Berne, \\ $\mathrm{CH}-3012$ Berne, Switzerland
}

\section{ABSTRACT}

Four lactating dairy cows were arranged in a $4 \times 4$ Latin square design to study the effect of intestinal glucose supply on milk fat synthesis. Glucose $(0,443$, 963 , and $2398 \mathrm{~g} / \mathrm{d}$ ) was continuously infused in the duodenum over 14-d periods. Grass silage-based diets were formulated to be isoenergetic and isonitrogenous and met 100 and $110 \%$ of energy and protein requirements according to INRA (1989). Mammary uptake of nutrients was estimated through assay of arteriovenous differences and blood flow measurements. Glucose infusions decreased arterial concentrations of acetate, $\beta$-hydroxybutyrate, and nonesterified fatty acids linearly and total glycerides curvilinearly. Milk fat yield was slightly decreased ( $-52 \mathrm{~g} / \mathrm{d}$ ) between 0 and $963 \mathrm{~g} / \mathrm{d}$ of glucose and milk fatty acid composition was modified by a marked decrease in long-chain fatty acids and an increase in de novo synthesis. The decrease in long-chain fatty acids, related to the decreased mammary uptake of plasma total glycerides, was likely due to a decrease in lipoprotein lipase and esterification activities. In regards to the evolution of metabolite concentrations in milk, the enhanced de novo synthesis and chain elongation was probably allowed by a greater availability of NADPH synthesized through pentose phosphate pathway. The greatest dose of glucose clearly decreased milk fat yield ( -234 $\mathrm{g} / \mathrm{d})$. A mammary cell mediated intracellular reaction likely caused a homothetic decrease in milk fatty acids. However, reduced synthesis was not due to a shortage of glycerol-3-phosphate because its milk concentration remained unchanged. In conclusion, changes in exoge-

Received December 26, 2001.

Accepted March 13, 2002.

Corresponding author: S. Rigout; e-mail: Sophie.Rigout@rennes. inra.fr. nous glucose supply, in cows fed a grass silage-based diet, decreased milk fat production and modified milk fatty acid composition.

(Key words: glucose infusion, mammary metabolism, milk fat, dairy cow)

Abbreviation key: AV = arteriovenous, $\mathbf{G 0}=0 \mathrm{~g} / \mathrm{d}$ of glucose infused in the duodenum, $\mathbf{G 1}=443 \mathrm{~g} / \mathrm{d}$ of glucose infused in the duodenum, $\mathbf{G 2}=963 \mathrm{~g} / \mathrm{d}$ of glucose infused in the duodenum, G3 $=2398 \mathrm{~g} / \mathrm{d}$ of glucose infused in the duodenum, $\mathbf{M B F}=$ mammary blood flow, PDI = protein truly digested in the small intestine.

\section{INTRODUCTION}

Diets for dairy cows in intensive housing are often rich in carbohydrates, which are not completely fermented in the rumen, leading to a potential amount of starch hydrolyzed to glucose in the intestine. Duodenal glucose infusions are known to reduce milk fat production (Hurtaud et al., 1998b). The composition of milk fatty acids is also modified. There are decreases in short- and long-chain fatty acids but a concomitant increase in medium-chain fatty acids (Hurtaud et al., 1998b). Understanding how glucose modifies milk fat production is an important aspect of dairy cow nutrition, but mechanisms by which glucose regulates milk fat synthesis are poorly understood. Several hypotheses have been suggested (Bauman and Griinari, 2001). The glucogenic-insulin theory, one of the first, suggested that increased release of insulin linked to an increased availability of glucose may slow down lipolysis and stimulate both NEFA reesterification and lipogenesis in the adipose tissue (Vernon, 1981). However, in duodenal glucose infusion studies (Lemosquet et al., 1997; Hurtaud et al., 1998b; Hurtaud et al., 2000; Rigout et al., 2002a), it is difficult to relate the decreased availability of milk fat precursors to an increased insulin secretion because of the small varia- 
tion in insulin concentrations. Moreover, the insulin mechanism has recently been intensely evaluated using long-term euglycemic-hyperinsulinemic clamp studies (McGuire et al., 1995; Griinari et al., 1997; Mackle et al., 1999; Bequette et al., 2001), and a role for insulin in milk fat depression was not supported. On the other hand, it has also been postulated that trans $10-\mathrm{C}_{18: 1}$ or related metabolites could be the cause of milk fat depression (Bauman and Griinari, 2001); however, their implication in milk fat decrease during glucose infusions seems to be challenged, as transfatty acid percentage and production in milk decreased (Rigout et al., accepted). Nevertheless, specifically trans 10 , cis 12 conjugated linoleic acid plays a bigger role in regulating milk fat synthesis than trans 10$\mathrm{C}_{18: 1}$ (Loor and Herbein, 1998; Chouinard et al., 1999; Baumgard et al., 2000).

To our knowledge, no direct measurement of mammary metabolism has been reported to understand how milk fat precursors are utilized by the mammary gland in response to graded amounts of duodenal glucose. However, it is known that mammary uptake of milk fat precursors depends on their arterial availability (Rulquin, 1997) and that jugular blood concentrations of milk fat precursors decreased in response to duodenal glucose infusions (Hurtaud et al., 1998b, 2000). Thus, in the present study, arteriovenous differences of milk fat precursors and blood flow were measured to describe the mechanisms involved in milk fat depression occurring during duodenal glucose infusions. Complementary data on glucose metabolism and milk production for this study have been presented previously (Rigout et al., 2002a).

\section{MATERIALS AND METHODS}

\section{Cows, Treatments, and Feeding}

Experimental details for this study have been reported (Rigout et al., 2002a). Briefly, four multiparous Holstein cows ( $635 \pm 52 \mathrm{~kg}$ of BW; $81 \pm 21 \mathrm{DIM} ; 32 \pm 2$ $\mathrm{kg} / \mathrm{d}$ of milk) were used in the experiment. Treatments were continuous duodenal infusions of graded amounts of glucose with equal supplies of $\mathrm{NE}_{\mathrm{L}}$ and protein truly digested in the small intestine (PDI; Institut National de la Recherche Agronomique, 1989). Glucose was infused at rates of $0,443,963$, and 2398 g/d (G0, G1, G2, and G3, respectively). To avoid the confounding effect of an increasing supply of energy from glucose and to keep energy and protein constant among treatments, $0.46 \mathrm{~kg}$ of grass silage and $1.62 \mathrm{~kg}$ of energy concentrate were replaced with $1.0 \mathrm{~kg}$ of glucose and $0.50 \mathrm{~kg}$ of soybean meal, assuming that 1 $\mathrm{kg}$ of glucose provided $2.75 \mathrm{Mcal}$ of $\mathrm{NE}_{\mathrm{L}}$ and $0 \mathrm{~g}$ of PDI (Armstrong and Blaxter, 1961). The combinations of diet plus infusion were formulated to provide 100 and $110 \%$ of energy and protein requirements (Institut National de la Recherche Agronomique, 1989). The experiment was conducted according to a $4 \times 4$ Latin square design over successive 14-d periods ( $9 \mathrm{~d}$ of adaptation and $5 \mathrm{~d}$ of measure).

The basal diet $(66 \% \mathrm{DM}, 17 \% \mathrm{CP}, 46 \% \mathrm{NDF}, 1.74$ $\mathrm{MCal} / \mathrm{d}$ ) consisted of $63.9 \%$ large bale grass silage, $7.1 \%$ formaldehyde-treated soybean meal, $27.7 \%$ energy concentrate (DM basis) supplemented with minerals and vitamins $(300 \mathrm{~g} / \mathrm{d})$ and with L-Lys HCl (11 $\mathrm{g} / \mathrm{d}$; Ajinomoto Co. Inc., Tokyo, Japan) and DL-Met (16 g/d; Rhône-Poulenc, Commentry, France) according to recommendations of Rulquin et al. (1993). The energy concentrate was mainly composed of barley, wheat, and dehydrated beet pulps. The composition of feedstuffs and details of diet formulation has been reported in Rigout et al. (2002a).

\section{Surgical Preparation}

Six months before calving, cows were fitted with a proximal T-shaped duodenal cannula placed 10 to 15 $\mathrm{cm}$ from the pylorus. Two or three months before the beginning of the experiment, cows were surgically prepared to estimate the mammary uptake of nutrients according to the methods described by Guinard et al. (1994). Two catheters were placed in the left carotid artery and the left subcutaneous abdominal vein to measure udder arteriovenous (AV) differences (Rigout et al., 2002a). A transit time ultrasonic flow probe (Transonic Systems Inc., Ithaca, NY) was placed around the left external pudic artery before the Sshaped bend in the artery to measure mammary blood flow (MBF). The four cows were housed in individual tie stalls. Grass silage was offered three times per day $(25 \%$ at $0700 \mathrm{~h}, 25 \%$ at $1300 \mathrm{~h}, 50 \%$ at $1900 \mathrm{~h})$ and concentrate eight times per day in equal portions. Access to feed was limited to $1 \mathrm{~h}$ every $3 \mathrm{~h}$ starting at 0700 .

\section{Measurements and Sampling}

The MBF was measured throughout the experiment, but the other measurements were performed during the second week of each period. On $\mathrm{d} 13$ at $0.5,2.5$, $4.5,6.5,8.5$, and $10.5 \mathrm{~h}$ after the morning milking, blood was collected simultaneously from the artery and vein with syringes containing $21 \pm 9 \mathrm{IU}$ of heparin (S-Monovette, $7.5 \mathrm{ml}$; Sarstedt, Nümbrecht, Germany) for the determination of acetate (Guynn and Veech, 1975), BHBA (McMurray et al., 1984), NEFA (Duncombe, 1964), and total glycerides (Bucolo and David, 1973). Blood was collected only from artery with syrin- 
ges containing $1.6 \pm 0.4 \mathrm{mg} / \mathrm{ml}$ of potassium-EDTA (Sarstedt) for hormone determination. Cows were standing during blood sampling. Plasma concentrations of metabolites other than hormones were measured on a multiparameter analyzer (KONE Instruments Corporation, Espoo, Finland).

Heparinized plasma was analyzed for NEFA using an enzymatic kit (acyl-coA synthetase, acyl-coA carboxylase method; Wako kit, Oxoid S.A., Dardilly, France) and total glyceride (lipase, glycerol kinase, glycerol-3-P oxidase, peroxidase method; Biotrol Diagnostic, Chennevière les Louvres, France). Intra-assay coefficient of variation was $0.9 \%$ for NEFA and $0.1 \%$ for total glyceride.

Deproteinized plasma (with $50 \%$, vol/vol, $\mathrm{HCLO}_{4}$ by filtration) was analyzed for BHBA (BHBA dehydrogenase method; Sigma, Saint-Quentin Fallavier, France) and for acetate (acetyl-coA synthetase, citrate synthetase, malate dehydrogenase method; Sigma, SaintQuentin Fallavier, France). Intraassay coefficient of variation was $0.4 \%$ for BHBA and $0.8 \%$ for acetate.

Cortisol, triiodothyronine, and thyroxine were measured by radioimmunoassay, as described by Hammon and Blum (1998). Intraassay coefficient of variation was $<10 \%$ for these hormones.

Cows were milked twice daily at 0630 and $1830 \mathrm{~h}$. Since blood was sampled on the left artery and vein, each half udder was milked separately to obtain a true balance for each nutrient on a half udder basis. Milk yield for each half udder was assayed for fat content by infrared analysis (Milkoscan; Foss Electric, Hillerod, Denmark). On d 14, $100 \mathrm{ml}$ of milk was taken from the left udder of each cow at the morning milking for the determination of milk fatty acids and metabolites concentrations.

To determine milk fatty acids, we extracted lipids from $1 \mathrm{ml}$ of milk fat according to Bauchard and Duboisset (1983) using $0.5 \mathrm{ml}$ of ethanol/HCl (4/1, vol/ vol) solution followed by $0.5 \mathrm{ml}$ of hexane. Milk fatty acids were then transesterified with $1 \mathrm{ml}$ of a butanol/ $\mathrm{HCl}(100 / 5$, vol/vol) followed by $2 \mathrm{ml}$ of hexane. Fatty acid butyl esters in hexane were then injected into a gas chromatograph (Varian 3400, Les Ulis, France) equipped with an electron ionization detector. Separation of fatty acid butyl esters was performed with a OV-1 fused silica capillary column $(25 \mathrm{~m} \times 0.32 \mathrm{~mm}$ i.d.). The carrier gas was helium. The oven temperature was programmed from 70 to $220^{\circ} \mathrm{C}$ at $100^{\circ} \mathrm{C} / \mathrm{min}$ and held for $32^{\circ} \mathrm{min}$. Injector and detector were at 220 and $250^{\circ} \mathrm{C}$, respectively.

For the determination of milk metabolites (citrate, isocitrate, oxoglutarate, glycerol-3-P, 6-phosphogluconate, malate, lactate and acetate), milk was immediately deproteinized with $5 M \mathrm{HCLO}_{4}$ before storage at $-20^{\circ} \mathrm{C}$ and later analyzed according to the methods of Faulkner (1980).

\section{Statistical Analysis}

The data were analyzed using a model for a Latin square with cow, period, treatment as independent variables. The residual error term was used to test for significance of cow, period, and treatment. In addition, the linear, quadratic, and cubic effects of glucose infusions were determined, using the residual error term. Because the treatment doses were not equally spaced, specific coefficients for each infusion amount $(0,1,2$, and 6) were used to avoid a biased comparison as described by Gill (1986). The calculations were done using PROC GLM of SAS (1990). Results were expressed as least squares means with root means squares errors because of missing values for one period of one cow and two missing values for the ratios associated with glucose-6-P.

\section{RESULTS}

As planned, feed intake decreased linearly; however, total $\mathrm{NE}_{\mathrm{L}}$ intake was unaffected by treatments (Table 1). Duodenal infusions of glucose quadratically increased milk yield, linearly decreased $(P<0.001)$ milk fat yield $(-20 \%)$ and curvilinearly decreased milk fat content $(-19 \%)$. However, the major part of the milk fat yield decrease (-17\%) occurred between G2 and G3, and the same was observed for FCM. As a consequence, $\mathrm{NE}_{\mathrm{L}}$ balance increased linearly $(P<0.05)$.

\section{Milk Fat Precursors}

Duodenal glucose infusions reduced on the whole, arterial concentrations of milk fat precursors (Table 2). Arterial concentrations of acetate, BHBA, and NEFA decreased linearly by 40,63 , and $55 \%$, respectively. Arterial concentrations of total glycerides decreased curvilinearly by $35 \%$.

Although arterial concentrations of milk fat precursors were dramatically decreased, their arterial fluxes (arterial concentrations $\times$ mammary plasma flow) were less affected because mammary plasma flow increased curvilinearly (Table 2). Arterial fluxes of acetate and total glycerides remained unchanged. Arterial flux of BHBA was decreased although not significantly by $45 \%$, and arterial flux of NEFA tended $(P=0.093)$ to decrease linearly.

\section{Mammary Utilization of Milk Fat Precursors}

The AV differences of acetate, BHBA, and total glycerides decreased linearly or curvilinearly with in- 
Table 1. Effect of duodenal infusions of glucose on feed and energy intake, energy balance, milk, FCM, milk fat content, and yield.

\begin{tabular}{|c|c|c|c|c|c|c|c|c|}
\hline & \multicolumn{4}{|c|}{ Glucose $^{1}$} & \multirow[b]{2}{*}{$\mathrm{RMSE}^{2}$} & \multicolumn{3}{|c|}{ Effect } \\
\hline & G0 & G1 & G2 & G3 & & Linear & Quadratic & Cubic \\
\hline & & & & & & & $-P-$ & 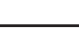 \\
\hline Feed intake, kg/d & 18.7 & 18.0 & 18.0 & 14.7 & 0.95 & 0.002 & 0.381 & 0.559 \\
\hline $\mathrm{NE}_{\mathrm{L}}$ intake $^{3}, \mathrm{Mcal} / \mathrm{d}$ & 32.4 & 32.4 & 33.9 & 32.1 & 1.99 & 0.743 & 0.317 & 0.566 \\
\hline $\mathrm{NE}_{\mathrm{L}}$ balance, $\mathrm{Mcal} / \mathrm{d}$ & 0.7 & 1.4 & 2.4 & 3.7 & 1.59 & 0.044 & 0.561 & 0.826 \\
\hline Milk, kg/d & 25.5 & 26.6 & 27.8 & 25.0 & 1.48 & 0.314 & 0.043 & 0.791 \\
\hline FCM, kg/d & 27.5 & 26.8 & 27.7 & 23.8 & 0.99 & 0.002 & 0.111 & 0.254 \\
\hline \multicolumn{9}{|l|}{ Fat } \\
\hline$\%$ & 4.55 & 4.04 & 3.98 & 3.69 & 0.110 & $<0.001$ & 0.005 & 0.072 \\
\hline $\mathrm{g} / \mathrm{d}$ & 1155 & 1078 & 1103 & 921 & 35.6 & $<0.001$ & 0.568 & 0.098 \\
\hline
\end{tabular}

${ }^{1}$ Duodenal infusions of glucose: G0 = 0 g/d; G1 = $443 \mathrm{~g} / \mathrm{d}$; G2 $=963 \mathrm{~g} / \mathrm{d}$; G3 = $2398 \mathrm{~g} / \mathrm{d}$.

${ }^{2}$ Root mean squares error.

${ }^{3}$ Including energy provided by glucose infusion.

Table 2. Effect of duodenal infusions of glucose on mammary blood (MBF) and plasma flows (MPF), arterial concentrations, and mammary utilization of acetate, BHBA, NEFA and total glycerides.

\begin{tabular}{|c|c|c|c|c|c|c|c|c|}
\hline & \multicolumn{4}{|c|}{ Glucose $^{1}$} & \multirow[b]{2}{*}{$\mathrm{RMSE}^{2}$} & \multicolumn{3}{|c|}{ Effect } \\
\hline & G0 & G1 & G2 & G3 & & Linear & Quadratic & Cubic \\
\hline & & & & & & & $-P$ & 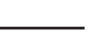 \\
\hline $\mathrm{MBF}, \mathrm{L} / \mathrm{min}$ & 5.22 & 6.33 & 6.89 & 7.56 & 0.552 & 0.003 & 0.042 & 0.711 \\
\hline & 3.96 & 4.89 & 5.26 & 5.88 & 0.416 & 0.002 & 0.039 & 0.561 \\
\hline \multicolumn{9}{|c|}{$\begin{array}{l}\text { MPF, L/min } \\
\text { Arterial concentrations }{ }^{3}\end{array}$} \\
\hline Acetate & 13.0 & 10.4 & 10.0 & 7.8 & 1.39 & 0.005 & 0.146 & 0.395 \\
\hline BHBA & 13.5 & 6.8 & 6.8 & 5.0 & 4.24 & 0.077 & 0.144 & 0.401 \\
\hline NEFA & 92.6 & 74.7 & 50.7 & 41.4 & 16.99 & 0.010 & 0.075 & 0.647 \\
\hline Total glycerides & 72.3 & 62.6 & 54.9 & 47.2 & 3.23 & $<0.001$ & 0.006 & 0.943 \\
\hline \multicolumn{9}{|l|}{ Arterial fluxes ${ }^{4}$} \\
\hline Acetate & 30.8 & 30.7 & 31.4 & 27.4 & 3.52 & 0.184 & 0.495 & 0.815 \\
\hline BHBA & 31.7 & 20.9 & 21.6 & 17.4 & 8.82 & 0.127 & 0.280 & 0.477 \\
\hline NEFA & 221 & 210 & 160 & 146 & 52.4 & 0.093 & 0.391 & 0.576 \\
\hline Total glycerides & 17.0 & 18.0 & 17.4 & 16.7 & 2.01 & 0.578 & 0.634 & 0.593 \\
\hline \multicolumn{9}{|c|}{ Arteriovenous differences ${ }^{3}$} \\
\hline Acetate & 8.99 & 7.53 & 6.69 & 5.10 & 1.135 & 0.006 & 0.195 & 0.834 \\
\hline BHBA & 4.47 & 3.17 & 2.94 & 1.85 & 0.898 & 0.014 & 0.224 & 0.533 \\
\hline NEFA & -0.33 & -8.31 & -15.57 & -17.56 & 11.008 & 0.105 & 0.227 & 0.924 \\
\hline Total glycerides & 32.3 & 23.4 & 16.7 & 8.8 & 4.33 & 0.001 & 0.033 & 0.987 \\
\hline \multicolumn{9}{|l|}{ Extraction rates, \% } \\
\hline Acetate & 69.1 & 71.6 & 66.6 & 65.1 & 3.33 & 0.075 & 0.896 & 0.179 \\
\hline BHBA & 37.8 & 43.2 & 42.7 & 37.3 & 5.12 & 0.449 & 0.133 & 0.574 \\
\hline NEFA & -7.5 & -16.2 & -31.2 & -42.4 & 17.45 & 0.038 & 0.353 & 0.737 \\
\hline Total glycerides & 44.2 & 37.0 & 30.6 & 18.8 & 4.48 & 0.001 & 0.125 & 0.942 \\
\hline \multicolumn{9}{|l|}{ Mammary uptake ${ }^{5}$} \\
\hline Acetate & 21.0 & 22.0 & 20.9 & 17.9 & 2.93 & 0.114 & 0.570 & 0.693 \\
\hline BHBA & 10.3 & 9.4 & 9.2 & 6.5 & 2.23 & 0.057 & 0.973 & 0.840 \\
\hline NEFA & -0.07 & -2.93 & -4.86 & -6.11 & 3.096 & 0.056 & 0.200 & 0.959 \\
\hline Total glycerides & 7.35 & 6.60 & 5.24 & 3.11 & 0.282 & $<0.001$ & 0.019 & 0.119 \\
\hline Uptake/milk output ${ }^{6}$ & 1.90 & 2.04 & 1.79 & 1.74 & 0.333 & 0.385 & 0.965 & 0.467 \\
\hline
\end{tabular}

${ }^{1}$ Duodenal infusions of glucose: G0 = $0 \mathrm{~g} / \mathrm{d} ; \mathrm{G} 1=443 \mathrm{~g} / \mathrm{d} ; \mathrm{G} 2=963 \mathrm{~g} / \mathrm{d} ; \mathrm{G} 3=2398 \mathrm{~g} / \mathrm{d}$.

${ }^{2}$ Root mean squares error.

${ }^{3}$ Arterial concentrations and arteriovenous differences are expressed in $\mathrm{mg} / 100 \mathrm{ml}$ for acetate and BHBA, $\mu \mathrm{mol} / \mathrm{L}$ for NEFA, and $\mu \mathrm{mol} / \mathrm{L}$ for triglycerides.

${ }^{4}$ Arterial fluxes (arterial concentrations $\times$ mammary plasma flow) are expressed for one half udder in g/ $\mathrm{h}$ for acetate and BHBA, in $\mathrm{mmol} / \mathrm{h}$ for total glycerides and in $\mu \mathrm{mol} / \mathrm{h}$ for NEFA.

${ }^{5}$ Expressed in $\mathrm{g} / \mathrm{h}$ for acetate and BHBA, $\mathrm{mmol} / \mathrm{h}$ for NEFA and total glycerides.

${ }^{6}$ Calculated from the mammary uptake of milk fat precursors (acetate, BHBA, and total glycerides) estimated over $12 \mathrm{~h}$ on one half udder and from the corresponding milk fat yield. 
creasing infusions of glucose (Table 2). Mammary AV differences of NEFA were negative and tended $(P=$ $0.11)$ to decrease linearly.

Results on mammary extraction rates varied according to the fat nutrients. Those of acetate and total glycerides tended to decrease or decreased linearly. Mammary extraction rates of BHBA remained unchanged, whereas mammary release rates of NEFA increased linearly.

Mammary uptake of acetate remained unchanged, whereas mammary uptake of BHBA decreased linearly $(P=0.057)$ by $37 \%$ with duodenal glucose infusions (Table 2). However, mammary uptake of BHBA was relatively constant between G0 and G2, and the major part of its decrease (-29\%) occurred between G2 and G3. Mammary uptake of total glycerides decreased curvilinearly, and mammary release of NEFA concomitantly increased linearly with treatments. The ratio of mammary uptake of milk fat precursors to milk fat output was above 1 and remained unchanged with treatments (Table 2).

\section{Milk Fatty Acid Composition and Production}

The proportion of even short-chain fatty acids remained unchanged, despite a slight numerical decrease (Tables 3 and 4). Moreover, the percentage of $\mathrm{C}_{8: 0}$ increased quadratically with duodenal infusions of glucose. The production of $\mathrm{C}_{4: 0}$ and $\mathrm{C}_{6: 0}$ decreased linearly and that of $\mathrm{C}_{8: 0}$ increased curvilinearly.

The percentage and production of even mediumchain fatty acids increased curvilinearly and quadratically (i.e., it decreased only at G3), respectively. The percentage of $\mathrm{C}_{16}$ fatty acid group increased linearly, and its production tended to decrease linearly. Nevertheless, the yield of de novo synthesized fatty acids increased quadratically by $13 \%$, reaching a maximum at G2.

The percentage and production of even long-chain fatty acids decreased curvilinearly and the percentage and production of $\mathrm{C}_{17}$ fatty acid group and trans 10 and trans $11-\mathrm{C}_{18: 1}$ decreased linearly.

\section{Milk Metabolites}

Milk glucose-6-P concentrations tended to increase linearly with treatments (Table 5). Glucose infusions curvilinearly decreased concentrations of citrate and malate in milk. Concentrations of isocitrate decreased quadratically and oxoglutarate, linearly. In contrast, concentrations of glycerol-3-P, 6-phosphogluconate, lactate and acetate in milk remained unchanged. The ratios of citrate to glucose-6-P and oxoglutarate to isocitrate decreased or tended to decrease linearly, whereas the ratio of isocitrate to glucose-6-P was unaffected. At the same time, ratios of glycerol-3-P and 6-phosphogluconate to glucose-6-P remained unchanged.

\section{DISCUSSION}

\section{Duodenal Glucose Decreased Milk Fat}

With equal energy supplied, duodenal glucose infusion of about $1 \mathrm{~kg} / \mathrm{d}$ decreased milk fat yield $(-4.5 \%)$ and composition $(-12.5 \%)$. When about $2.4 \mathrm{~kg} / \mathrm{d}$ was infused, glucose substantially decreased both milk fat yield and composition $(\sim 20 \%)$.

The decrease in milk fat content was greater than is found in the literature (Lemosquet et al., 1997; Oldick et al., 1997; Hurtaud et al., 1998ab, 2000; Hurtaud and Rulquin, 1999). The decrease in milk fat yield obtained for G2 was lower than reported in the literature (-8\%), but the decrease obtained for G3 was similar to that reported by Hurtaud et al. (1998b) when equivalent doses of glucose infused were associated with corn silage-based diets. But response was about twofold greater when the diet was based on grass silage (Hurtaud et al., 2000).

Duodenal glucose infusions modified milk fatty acid composition by decreasing long-chain fatty acids and increasing medium-chain fatty acids, as the percentage of short-chain fatty acids was quite constant between G0 and G2, confirming the previous results (Hurtaud et al., 1998b, 2000). To understand the mechanisms involved in the decrease in milk fat, results of G3 will be analyzed separately because it was an exacerbated physiological response.

\section{Duodenal Glucose Decreased Arterial Concentrations of Milk Fat Precursors}

In the present study, the reduced arterial concentrations of the milk fat precursors acetate, BHBA, and total glycerides were probably partially related to the decrease in feed DMI $(-0.7 \mathrm{~kg} / \mathrm{d}$ between G0 and G1 or G2) (Rigout et al., 2002a) as well as a decrease in the rate of adipose tissue lipolysis. The decrease in feed DMI is a direct consequence of the experimental design, since a part of VFA resulting from the ruminal fermentation of the diet was substituted by duodenal infusion of glucose. On the other hand, glucose has already been observed to directly decrease plasma arterial concentrations of NEFA, BHBA and acetate, resulting from an increase in fatty acid reesterification in adipose tissue (Vernon, 1981) or a decrease in the balance lipolysis/lipogenesis (Griinari et al., 1997). In this study, glucose infusions may have acted on the concentrations of milk fat precursors directly or alter- 
Table 3. Effect of duodenal infusions of glucose on milk fatty acid composition.

\begin{tabular}{|c|c|c|c|c|c|c|c|c|}
\hline & \multicolumn{4}{|c|}{ Glucose $^{1}$} & \multirow[b]{2}{*}{$\mathrm{RMSE}^{2}$} & \multicolumn{3}{|c|}{ Effect } \\
\hline & G0 & G1 & G2 & G3 & & Linear & Quadratic & Cubic \\
\hline & & & & & & & $-P-$ & - \\
\hline \multicolumn{9}{|l|}{ Fatty acids, $\%$} \\
\hline $\mathrm{C}_{4}$ & 3.01 & 2.67 & 2.61 & 2.54 & 0.229 & 0.070 & 0.121 & 0.552 \\
\hline $\mathrm{C}_{5}$ & 0.018 & 0.021 & 0.024 & 0.030 & 0.003 & 0.002 & 0.284 & 0.842 \\
\hline $\mathrm{C}_{6}$ & 2.33 & 2.35 & 2.30 & 2.25 & 0.083 & 0.162 & 0.914 & 0.624 \\
\hline $\mathrm{C}_{7}$ & 0.019 & 0.027 & 0.035 & 0.046 & 0.005 & 0.001 & 0.078 & 0.864 \\
\hline $\mathrm{C}_{8}$ & 1.43 & 1.58 & 1.56 & 1.56 & 0.047 & 0.063 & 0.016 & 0.068 \\
\hline $\mathrm{C}_{9}$ & 0.023 & 0.035 & 0.047 & 0.071 & 0.012 & 0.003 & 0.348 & 0.914 \\
\hline $\mathrm{C}_{10}$ & 3.17 & 3.95 & 3.85 & 4.04 & 0.272 & 0.020 & 0.035 & 0.114 \\
\hline $\mathrm{C}_{11}$ & 0.041 & 0.063 & 0.088 & 0.132 & 0.019 & 0.001 & 0.218 & 0.802 \\
\hline $\mathrm{C}_{12}$ & 3.50 & 4.65 & 4.66 & 5.28 & 0.367 & 0.002 & 0.029 & 0.129 \\
\hline $\mathrm{C}_{13}$ & 0.077 & 0.103 & 0.128 & 0.158 & 0.017 & 0.001 & 0.078 & 0.847 \\
\hline $\mathrm{C}_{14: 1}$ & 0.87 & 1.22 & 1.36 & 1.49 & 0.103 & 0.001 & 0.005 & 0.389 \\
\hline $\mathrm{C}_{14}$ & 12.1 & 13.8 & 13.9 & 13.4 & 0.71 & 0.222 & 0.017 & 0.326 \\
\hline iso- $\mathrm{C}_{15}$ & 0.28 & 0.25 & 0.27 & 0.25 & 0.015 & 0.044 & 0.776 & 0.070 \\
\hline $\mathrm{C}_{15: 1}$ & 0.51 & 0.48 & 0.48 & 0.42 & 0.018 & 0.001 & 0.586 & 0.305 \\
\hline $\mathrm{C}_{15}$ & 1.11 & 1.23 & 1.42 & 1.55 & 0.143 & 0.008 & 0.144 & 0.593 \\
\hline $\mathrm{C}_{16: 1}$ & 1.74 & 1.87 & 2.31 & 2.90 & 0.232 & 0.001 & 0.363 & 0.351 \\
\hline $\mathrm{C}_{16}$ & 37.6 & 37.4 & 39.6 & 41.9 & 1.25 & 0.003 & 0.696 & 0.218 \\
\hline iso- $\mathrm{C}_{17}$ & 0.38 & 0.35 & 0.35 & 0.33 & 0.050 & 0.295 & 0.531 & 0.760 \\
\hline $\mathrm{C}_{17: 1}$ & 0.82 & 0.77 & 0.71 & 0.75 & 0.073 & 0.325 & 0.154 & 0.781 \\
\hline $\mathrm{C}_{17}$ & 0.62 & 0.56 & 0.53 & 0.53 & 0.054 & 0.103 & 0.131 & 0.822 \\
\hline $\mathrm{C}_{18: 2}$ & 1.53 & 1.52 & 1.46 & 1.38 & 0.084 & 0.044 & 0.878 & 0.746 \\
\hline $\mathrm{C}_{18: 3}$ & 0.39 & 0.44 & 0.41 & 0.45 & 0.057 & 0.286 & 0.880 & 0.401 \\
\hline $\mathrm{C}_{18: 1}$ & 16.4 & 14.6 & 13.5 & 12.0 & 1.30 & 0.007 & 0.127 & 0.843 \\
\hline trans $-10 \mathrm{C}_{18: 1}$ & 0.71 & 0.67 & 0.57 & 0.51 & 0.064 & 0.007 & 0.139 & 0.410 \\
\hline trans-11 $\mathrm{C}_{18: 1}$ & 1.38 & 1.37 & 1.27 & 1.02 & 0.093 & 0.002 & 0.763 & 0.492 \\
\hline $\mathrm{C}_{18: 0}$ & 10.02 & 8.13 & 6.48 & 4.97 & 0.625 & 0.001 & 0.005 & 0.818 \\
\hline \multicolumn{9}{|l|}{ Fatty acids, \% } \\
\hline $\mathrm{C}_{4: 0}$ to $\mathrm{C}_{8: 0}$ & 6.77 & 6.61 & 6.47 & 6.35 & 0.304 & 0.131 & 0.452 & 0.983 \\
\hline $\mathrm{C}_{5: 0}$ to $\mathrm{C}_{9: 0}$ & 0.060 & 0.083 & 0.106 & 0.147 & 0.018 & 0.001 & 0.193 & 0.880 \\
\hline $\mathrm{C}_{10: 0}$ to $\mathrm{C}_{14}$ & 19.6 & 23.6 & 23.8 & 24.2 & 1.25 & 0.012 & 0.011 & 0.160 \\
\hline $\mathrm{C}_{11: 0}$ to $\mathrm{C}_{15: 0}$ & 2.02 & 2.12 & 2.39 & 2.51 & 0.186 & 0.012 & 0.170 & 0.471 \\
\hline $\mathrm{C}_{16: 0}+\mathrm{C}_{16: 1}$ & 39.3 & 39.2 & 41.9 & 44.8 & 1.28 & 0.001 & 0.584 & 0.180 \\
\hline iso- $\mathrm{C}_{17: 0}+\mathrm{C}_{17: 1}+\mathrm{C}_{17: 0}$ & 1.82 & 1.68 & 1.59 & 1.60 & 0.161 & 0.188 & 0.175 & 0.964 \\
\hline $\mathrm{C}_{18: 2}+\mathrm{C}_{18: 3}+\mathrm{C}_{18: 1}+\mathrm{C}_{18: 0}$ & 28.3 & 24.6 & 21.9 & 18.8 & 1.88 & 0.001 & 0.036 & 0.984 \\
\hline trans $-10 \mathrm{C}_{18: 1}+$ trans $-11 \mathrm{C}_{18: 1}$ & 2.09 & 2.05 & 1.83 & 1.53 & 0.139 & 0.002 & 0.580 & 0.406 \\
\hline De novo synthesis, $\%^{3}$ & 25.5 & 29.7 & 30.2 & 30.7 & 1.38 & 0.010 & 0.012 & 0.196 \\
\hline Unsaturated, \% & 24.3 & 22.9 & 22.1 & 21.0 & 1.61 & 0.042 & 0.296 & 0.904 \\
\hline Elongation index ${ }^{4}$ & 1.27 & 1.72 & 1.73 & 1.95 & 0.180 & 0.007 & 0.051 & 0.223 \\
\hline
\end{tabular}

${ }^{1}$ Duodenal infusions of glucose: G0 = 0 g/d; G1 = $443 \mathrm{~g} / \mathrm{d}$; G2 $=963 \mathrm{~g} / \mathrm{d}$; G3 = $2398 \mathrm{~g} / \mathrm{d}$.

${ }^{2}$ Root mean squares error.

${ }^{3}$ Represents the sum of percentages of even and odd fatty acids from $\mathrm{C}_{5: 0}$ to $\mathrm{C}_{15}$.

${ }^{4}$ Calculated as the ratio of $\left(\mathrm{C}_{10}+\mathrm{C}_{12}\right)$ to $\left(\mathrm{C}_{4}+\mathrm{C}_{6}\right)$.

natively changing hormonal pathways. Indeed, variations in arterial concentrations of hormones existed but were too small to explain the overall response. In response to increasing duodenal glucose infusions, the rate of appearance of glucose and glucose utilization by portal drained-viscera increased (Rigout et al., 2002a). During this time, arterial concentrations of insulin tended to increase and growth hormone tended to decrease (Rigout et al., 2002a). But concentrations of triiodothyronine, thyroxine, and cortisol remained unchanged (Table 6). Hence, the increasing rate of appearance of glucose associated with little change in hormonal secretion may have favored fatty acid reesterification.
Although arterial concentrations of milk fat precursors were decreased, the dramatic increase in mammary blood flow (Rigout et al., 2002a) and the consistency of arterial fluxes (arterial concentrations $\times$ mammary plasma flow; Table 2) show that the total delivery of milk fat precursors to the mammary gland was only slightly affected.

\section{Duodenal Glucose Decreased Mammary Uptake of Plasma Total Glycerides and Consequently Long-Chain Fatty Acids in Milk}

The decreased production of $\mathrm{C}_{18}$ fatty acid group accounted for $92 \%$ of the decreased fatty acids in milk 
Table 4. Effect of duodenal infusions of glucose on milk fatty acid production for an entire udder.

\begin{tabular}{|c|c|c|c|c|c|c|c|c|}
\hline & \multicolumn{4}{|c|}{ Glucose $^{1}$} & \multirow[b]{2}{*}{$\mathrm{RMSE}^{2}$} & \multicolumn{3}{|c|}{ Effect } \\
\hline & G0 & G1 & G2 & G3 & & Linear & Quadratic & Cubic \\
\hline & & & & & & & $-P-$ & - \\
\hline \multicolumn{9}{|l|}{ Fatty acids, g/d } \\
\hline $\mathrm{C}_{4: 0}$ to $\mathrm{C}_{8: 0}$ & 0.64 & 0.57 & 0.57 & 0.47 & 0.038 & 0.023 & 0.379 & 0.282 \\
\hline $\mathrm{C}_{5: 0}$ to $\mathrm{C}_{9: 0}, \times 10^{-3}$ & 4.67 & 5.97 & 7.72 & 9.09 & 1.52 & 0.011 & 0.172 & 0.723 \\
\hline $\mathrm{C}_{10: 0}$ to $\mathrm{C}_{14}$ & 0.92 & 1.04 & 1.07 & 0.92 & 0.087 & 0.354 & 0.031 & 0.657 \\
\hline $\mathrm{C}_{11: 0}$ to $\mathrm{C}_{15: 0}$ & 0.083 & 0.082 & 0.096 & 0.085 & 0.010 & 0.777 & 0.155 & 0.291 \\
\hline $\mathrm{C}_{16: 0}+\mathrm{C}_{16: 1}$ & 1.54 & 1.42 & 1.55 & 1.39 & 0.080 & 0.067 & 0.583 & 0.077 \\
\hline iso- $\mathrm{C}_{17: 0}+\mathrm{C}_{17: 1}+\mathrm{C}_{17: 0}$ & 0.065 & 0.057 & 0.056 & 0.046 & 0.005 & 0.005 & 0.292 & 0.444 \\
\hline $\mathrm{C}_{18: 2}+\mathrm{C}_{18: 3}+\mathrm{C}_{18: 1}+\mathrm{C}_{18: 0}$ & 0.97 & 0.80 & 0.71 & 0.52 & 0.049 & $<0.001$ & 0.019 & 0.276 \\
\hline trans $-10 \mathrm{C}_{18: 1}+$ trans $-11 \mathrm{C}_{18: 1}$ & 0.072 & 0.066 & 0.061 & 0.042 & 0.004 & $<0.001$ & 0.733 & 0.992 \\
\hline Unsaturated, g/d & 0.85 & 0.76 & 0.76 & 0.60 & 0.040 & $<0.001$ & 0.550 & 0.188 \\
\hline \multicolumn{9}{|l|}{ De novo synthesis ${ }^{3}$} \\
\hline Yield, g/d & 2.08 & 2.13 & 2.24 & 1.94 & 0.132 & 0.100 & 0.061 & 0.638 \\
\hline Uptake/milk output ${ }^{4}$ & $1.27^{5}$ & $1.33^{5}$ & 1.15 & 1.13 & 0.197 & 0.272 & 0.762 & 0.420 \\
\hline \multicolumn{9}{|c|}{${ }^{1}$ Duodenal infusions of glucose: $\mathrm{G} 0=0 \mathrm{~g} / \mathrm{d} ; \mathrm{G} 1=443 \mathrm{~g} / \mathrm{d} ; \mathrm{G} 2=963 \mathrm{~g} / \mathrm{d} ; \mathrm{G} 3=2398 \mathrm{~g} / \mathrm{d}$. } \\
\hline \multicolumn{9}{|c|}{${ }^{2}$ Root mean squares error. } \\
\hline \multicolumn{9}{|c|}{${ }^{3}$ Represents the sum of yields of even and odd fatty acids from $\mathrm{C}_{6: 0}$ to $\mathrm{C}_{16: 2}$. } \\
\hline $\begin{array}{l}{ }^{4} \text { Calculated from the mamm } \\
\text { one half udder and from the }\end{array}$ & $\begin{array}{l}\text { y uptal } \\
\text { correspc }\end{array}$ & $\begin{array}{l}\text { of mil } \\
\text { ading } y\end{array}$ & $\begin{array}{l}\text { fat pre } \\
\text { ld of de }\end{array}$ & $\begin{array}{l}\text { ursors } \\
\text { novo sy }\end{array}$ & $\begin{array}{l}\text { cetate an } \\
\text { thesized }\end{array}$ & BHBA & $\begin{array}{l}\text { stimated } \\
\text { cids. }\end{array}$ & r 12 \\
\hline
\end{tabular}

between G0 and G2. Milk long-chain fatty acids are known to come from fatty acids provided by the diet and adipose tissue (total glycerides and NEFA) in blood supplied to the mammary gland. Thus, the decrease of $\mathrm{C}_{18}$ fatty acid group in milk mirrored the linear decrease in mammary uptake of total glycerides. As previously reported (Miller et al., 1991; Rulquin, 1997), the AV differences of total glycerides are positively correlated with their arterial concentrations
(Figure 1). However, the slope between AV and arterial concentrations obtained in this study is about twofold greater than that noted by Rulquin (1997). This result indicates that the capacity of mammary tissue to extract total glycerides from blood circulation was rapidly decreased by duodenal glucose infusions. The decrease in mammary uptake of total glycerides probably reflects reduced lipoprotein lipase activity caused by glucose infusions. However, if the transport of total

Table 5. Effect of duodenal infusions of glucose on concentrations of milk metabolites (mmol/L) and their ratios $(\mathrm{mmol} / \mathrm{mmol})$.

\begin{tabular}{|c|c|c|c|c|c|c|c|c|}
\hline & \multicolumn{4}{|c|}{ Glucose $^{1}$} & \multirow[b]{2}{*}{$\mathrm{RMSE}^{2}$} & \multicolumn{3}{|c|}{ Effect } \\
\hline & G0 & G1 & G2 & G3 & & Linear & Quadratic & Cubic \\
\hline & & & & & & & $-P-$ & \\
\hline \multicolumn{9}{|l|}{ Metabolites $(\mathrm{mmol} / \mathrm{L})$} \\
\hline Glucose-6-P & 0.024 & 0.034 & 0.033 & 0.044 & 0.010 & 0.079 & 0.674 & 0.467 \\
\hline Citrate & 9.83 & 7.97 & 7.64 & 7.60 & 0.761 & 0.027 & 0.019 & 0.351 \\
\hline Isocitrate & 0.27 & 0.26 & 0.21 & 0.28 & 0.030 & 0.266 & 0.022 & 0.258 \\
\hline 2-Oxoglutarate & 0.20 & 0.13 & 0.11 & 0.10 & 0.040 & 0.039 & 0.052 & 0.630 \\
\hline Glycerol-3-P & 0.066 & 0.092 & 0.079 & 0.083 & 0.022 & 0.601 & 0.429 & 0.298 \\
\hline 6-Phosphogluconate & 0.085 & 0.103 & 0.093 & 0.119 & 0.038 & 0.293 & 0.994 & 0.632 \\
\hline L-malate & 0.53 & 0.30 & 0.25 & 0.22 & 0.080 & 0.007 & 0.010 & 0.301 \\
\hline Lactate & 0.12 & 0.15 & 0.05 & 0.05 & 0.100 & 0.300 & 0.635 & 0.416 \\
\hline Acetate & 0.16 & 0.12 & 0.17 & 0.13 & 0.038 & 0.582 & 0.760 & 0.229 \\
\hline \multicolumn{9}{|l|}{ Ratios (mmol/mmol) } \\
\hline Citrate/Glucose-6-P & 463 & 250 & 267 & 185 & 116.0 & 0.074 & 0.184 & 0.303 \\
\hline Isocitrate/Glucose-6-P & 12.1 & 8.3 & 7.2 & 7.0 & 2.78 & 0.146 & 0.148 & 0.665 \\
\hline 2-Oxoglutarate/Isocitrate & 0.75 & 0.51 & 0.50 & 0.35 & 0.113 & 0.008 & 0.103 & 0.281 \\
\hline Glycerol-3-P/Glucose-6-P & 2.71 & 2.83 & 2.68 & 1.98 & 0.734 & 0.208 & 0.659 & 0.862 \\
\hline 6-P-gluconate/Glucose-6-P & 3.82 & 3.44 & 3.38 & 2.73 & 1.706 & 0.472 & 0.929 & 0.915 \\
\hline
\end{tabular}

${ }^{1}$ Duodenal infusions of glucose: G0 = 0 g/d; G1 = 443 g/d; G2 = 963 g/d; G3 = 2398 g/d.

${ }^{2}$ Root mean squares error. 
Table 6. Effect of duodenal infusions of glucose on arterial blood concentrations of cortisol, triiodothyronine and thyroxine.

\begin{tabular}{|c|c|c|c|c|c|c|c|c|}
\hline & \multicolumn{4}{|c|}{ Glucose $^{1}$} & \multirow[b]{2}{*}{$\mathrm{RMSE}^{2}$} & \multicolumn{3}{|c|}{ Effect } \\
\hline & G0 & G1 & G2 & G3 & & Linear & Quadratic & Cubic \\
\hline & & & & & & $\longrightarrow$ & $-P$ & - \\
\hline Cortisol (ng/ml) & 7.25 & 5.61 & 5.94 & 6.53 & 2.725 & 0.958 & 0.483 & 0.693 \\
\hline Thyroxine (nmol/L) & 43.0 & 40.1 & 42.0 & 37.5 & 6.76 & 0.336 & 0.947 & 0.642 \\
\hline Triiodothyronine (nmol/L) & 0.598 & 0.641 & 0.769 & 0.703 & 0.180 & 0.516 & 0.319 & 0.677 \\
\hline
\end{tabular}

${ }^{1}$ Duodenal infusions of glucose: G0 = 0 g/d; G1 = 443 g/d; G2 = 963 g/d; G3 = 2398 g/d.

${ }^{2}$ Root mean squares error.

glycerides is diffusion limited, the increased $\mathrm{MBF}$ could have caused a reduction in uptake (Vernon and Peaker, 1983; Prosser et al., 1996).

The decrease in long-chain fatty acids could also be due to a decrease in intramammary esterification process. Indeed, the linear increase in NEFA mammary release associated to the linear decrease of total glycerides mammary uptake also demonstrate that the hydrolyzed fatty acids could not be esterified to glycerol-3-P to form triglycerides within the mammary gland. In this experiment, the reduction of esterification was not related to a shortage in glycerol because milk concentration of glycerol-3-P increased. The causes for this impaired esterification are unknown; however, a mechanism could be proposed. Emery (1973) suggested that acylation on sn-3 position of glycerol-3-P may regulate synthesis of milk triglycerides. Since this requires fatty acids like $\mathrm{C}_{4: 0}$ or $\mathrm{C}_{18: 1}$,

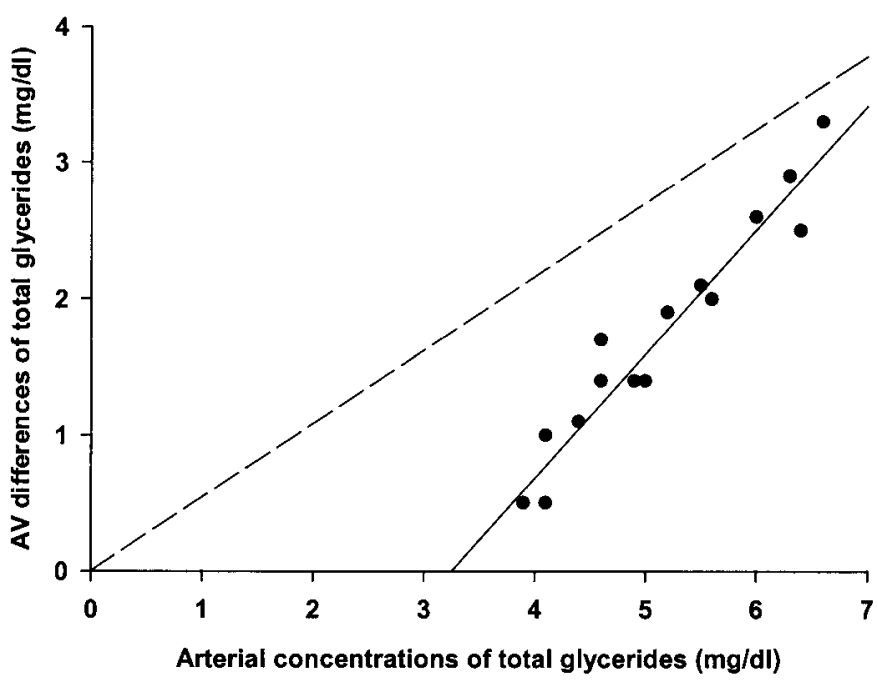

Figure 1. Relationship between arteriovenous (AV) differences and arterial concentrations (A) of plasma total glycerides (TG) of the present experiment (-); regression equation (-): AV differences TG $(\mathrm{mg} / \mathrm{dl})=0.91 \times \mathrm{A} \mathrm{TG}(\mathrm{mg} / \mathrm{dl})-2.96$. Regression equation of the relationship published by Rulquin (1997) (--): AV differences TG (mg/ $\mathrm{dl})=0.54 \times \mathrm{A} \mathrm{TG}(\mathrm{mg} / \mathrm{dl})$. which in this study were utilized for de novo synthesis $\left(\mathrm{C}_{4: 0}\right)$ and were less taken up by the udder $\left(\mathrm{C}_{18}\right)$, a shortage of these two substrates may have blocked the formation of milk triglycerides.

\section{Duodenal Glucose Infusions Increased De Novo Synthesis of Milk Fatty Acids}

The composition of milk fatty acids was also modified by the increase in milk fatty acid de novo synthesis and an increase in chain elongation, as the elongation index $\left[\left(\mathrm{C}_{10: 0}+\mathrm{C}_{12: 0}\right) /\left(\mathrm{C}_{4: 0}+\mathrm{C}_{6: 0}\right)\right]$ linearly increased (Table 3 ). The changes in milk fatty acid composition were totally different to changes that occur in normal dietary caused low fat milk syndrome, where shortand medium-chain fatty acids decrease and long-chain fatty acids increased (Davis and Brown, 1970; Bauman and Griinari, 2001). Although arterial concentrations of acetate and BHBA decreased linearly, their mammary uptake was not affected between G0 and G2. Moreover, although AV differences of BHBA and acetate linearly decreased, the efficiency of the mammary gland to extract them was not altered. The values of mammary extraction rates of acetate and BHBA were similar to values of Rulquin (1997) and Miller (1983). Additionally, the efficiency of mammary utilization of acetate and BHBA was increased, as the ratio of mammary uptake to milk output for short-chain fatty acids was greater than 1 for G0 and G1 and then was not different from 1 for G2.

The decrease in long-chain fatty acids may have allowed for an increase in de novo synthesis as it has been shown that longer chain fatty acids inhibit acetyl CoA carboxylase (Palmquist et al., 1993). The increase of de novo synthesis was also supported by the decrease of milk citrate concentrations. Moreover, an increase in energy could have also allowed an enhancement in mammary de novo lipogenesis because glucose availability for the udder was improved (Rigout et al., 2002a). The supplemental mammary glucose was not only used for lactose synthesis but may have also been used to generate energy via the Krebs cycle and 
NADPH via pentose phosphate pathway. However, the greater energy supply did not arise from the Krebs cycle because ratios of citrate and isocitrate to glucose6-P and oxoglutarate to isocitrate decreased with treatments. In contrast, milk concentrations of 6-phosphogluconate were greater in glucose treatments compared with G0 treatments and the ratio of 6-phosphogluconate to glucose-6-P remained unchanged. Thus, the glucose not utilized for lactose synthesis could have been used for greater synthesis of NADPH through the pentose phosphate pathway.

\section{High Glucose and Mammary Cell Function}

As indicated by a more severe decrease in feed DMI ( $-4 \mathrm{~kg} / \mathrm{d}$ between G0 and G3; Rigout et al., 2002a), the decrease in milk fat precursors in plasma was highest for G3 compared with the other treatments. However, the shortage of milk fat precursors was not the unique reason for decreased fat yield with the G3 treatment. Indeed, the reduction in milk fatty acids yield between G2 and G3 ( $-150 \mathrm{~g} / \mathrm{d}$ of fatty acids) occurred with similarly decreased production of short- and medium-chain fatty acids $(44 / 150 \mathrm{~g} / \mathrm{d}=29 \%), \mathrm{C}_{16}$ fatty acid group (41/ $150 \mathrm{~g} / \mathrm{d}=27 \%)$ and $\mathrm{C}_{18}$ fatty acid group $(65 / 150 \mathrm{~g} / \mathrm{d}$ $=44 \%$ ). The increase in mammary blood flow cannot explain the homothetic decrease in milk fatty acids in G3, because neither the efficiency of the mammary gland to extract acetate and BHBA, nor their mammary uptake were highly altered; thus, an intramammary disorder could be proposed as an explanation. As milk concentrations of glycerol-3-P were not affected by treatments, milk fatty acid decrease was not due to a reduced availability of this substrate to form milk triglycerides, because milk concentrations of this substrate was not affected by treatments. Ghyczy and Boros (2001) observed that an increase in the ratio of $\mathrm{NADPH}$ to $\mathrm{NADP}^{+}$resulted in a reducing stress that inhibited many enzymes including those of EmbdenMeyehof pathway. Therefore, as illustrated by the evolution of the ratio of 6-phosphogluconate to glucose-6$\mathrm{P}$, an increase in the ratio of $\mathrm{NADPH}$ to $\mathrm{NADP}^{+}$might be responsible in the inhibition of fat synthesis.

\section{CONCLUSIONS}

Results suggested that the decrease in milk fat yield and content by duodenal glucose infusions was due to a decrease of lipoprotein lipase activity and a decrease of intramammary esterification process. However, because of the great increase in MBF, the decrease of total glycerides mammary uptake may have been blood flow-dependent. Duodenal glucose infusions led also to an increase of de novo synthesis and chain elongation, by increasing energy source availability.

\section{ACKNOWLEDGMENTS}

The authors gratefully thank Y. Lebreton for assistance with surgeries; P. Lamberton and his team for their helpful assistance, care and feeding of cows; and M. Texier, S. Rigault, M. Vérité and S. Kerbrat for technical assistance; and C. Hurtaud and J. GuinardFlament for fruitful discussions in the preparation of the manuscript.

\section{REFERENCES}

Armstrong, D. G., and K. L. Blaxter. 1961. The utilization of energy of carbohydrate by ruminants. Pages 187-199 in Proc. 2nd Symp. Energy Metab. Eur. Assoc. Anim. Prod., Wagenningen, The Netherlands.

Bauchart, D., and F. Duboisset. 1983. Utilisation des colonnes capillaires de verre pour l'analyse des acides gras du lait. Cah. Techn. Inst. Natl. Rech. Agron. 1:37-46.

Bauman, D. E., and J. M. Griinari. 2001. Regulation and nutritional manipulation of milk fat: Low-fat milk syndrome. Livest. Prod. Sci. 70:15-29.

Baumgard, L. H., B. A. Corl, D. A. Dwyer, A. Saebo, and D. E. Bauman. 2000. Identification of the conjugated linoleic acid isomer that inhibits milk fat synthesis. Am. J. Physiol. 278:R179-R184.

Bequette, B. J., C. E. Kyle, C. E. Crompton, V. Buchan, and M. D. Hanigan. 2001. Insulin regulates milk production and mammary gland and hind-leg amino acid fluxes and blood flow in lactating goats. J. Dairy Sci. 84:241-255.

Bucolo, G., and H. David. 1973. Quantitative determination of serum triglycerides by the use of enzymes. Clin. Chem. 19:476-482.

Chouinard, P. Y., L. Corneau, A. Saebo, and D. E. Bauman. 1999. Milk yield and composition during abomasal infusion of conjugated linoleic acids in dairy cows. J. Dairy Sci. 82:2737-2745.

Davis, C. L., and R. E. Brown. 1970. Low-fat milk syndrome. Pages 545-565 in Physiology of Digestion and Metabolism in the Ruminant. A. T. Phillipson, eds. Oriel Press, Newcastle upon Tyne, UK.

Duncombe, W. G. 1964. The colorimetric micro-determination of non-esterified fatty acids in plasma. Clin. Chem. Acta 9:122.

Emery, R. S. 1973. Biosynthesis of milk fat. J. Dairy Sci. 56:1187-1195.

Faulkner, A. 1980. The presence of cellular metabolites in milk. Biochim. Biophys. Acta 630:141-145.

Ghyczy, M., and M. Boros. 2001. Electrophilic methyl groups present in the diet ameliorate pathological states induced by reductive and oxidative stress: a hypothesis. Br. J. Nutr. 85:409-414.

Gill, J. L., ed. 1986. Design and Analysis of Experiments in the Animal and Medical Sciences. Vol I and II. Iowa State Univ. Press, Ames, Iowa.

Griinari, J. M., M. A. McGuire, D. A. Dwyer, D. E. Bauman, and D. L. Palmquist. 1997. Role of insulin in the regulation of milk fat synthesis in dairy cows. J. Dairy Sci. 80:1076-1084.

Guinard, J., H. Rulquin, and R. Vérité. 1994. Effect of graded levels of duodenal infusions of casein on mammary uptake in lactating cows. 1. Major nutrients. J. Dairy Sci. 77:2221-2231.

Guynn, R. W., and R. L. Veech. 1975. Enzymatic determination of acetate. Meth. Enzym. 35:302-307.

Hammon, H. M., and J. W. Blum. 1998. Metabolic and endocrine traits of neonatal calves are influenced by feeding colostrum for different durations or only milk replacer. J. Nutr. 128:624-632.

Hurtaud, C., S. Lemosquet, and H. Rulquin. 2000. Effect of graded duodenal infusions of glucose on yield and composition of milk from dairy cows. 2. Diets based on grass silage. J. Dairy Sci. 83:2952-2962.

Hurtaud, C., and H. Rulquin. 1999. Effect of the nature of energy source (propionic acid, glucose or starch) on milk yield and com- 
position in dairy cows. [French]. Renc.Rech.Ruminants 6:103106. (Abstr.)

Hurtaud, C., H. Rulquin, and R. Vérité. 1998b. Effects of graded duodenal infusions of glucose on yield and composition of milk from dairy cows. 1. Diets based on corn silage. J. Dairy Sci. 81:3239-3247.

Hurtaud, C., H. Rulquin, and R. Vérité. 1998a. Effects of level and type of energy source (volatile fatty acids or glucose) on milk yield, composition and coagulating properties in dairy cows. Reprod. Nutr. Dev. 38:315-330.

Institut National de la Recherche Agronomique. 1989. Introduction. Feeding standards for ruminants. Pages 15-22 in Ruminant Nutrition. Recommended Allowances and Feed Tables. R. Jarrige, ed. John Libbey, Eurotext, London, England.

Lemosquet, S., N. Rideau, H. Rulquin, P. Faverdin, J. Simon, and R. Vérité. 1997. Effects of a duodenal glucose infusion on the relationship between plasma concentrations of glucose and insulin in dairy cows. J. Dairy Sci. 80:2854-2865.

Loor, J. J., and J. H. Herbein. 1998. Exogenous conjugated linoleic acid isomers reduce bovine milk fat concentration and yield by inhibiting de novo fatty acid synthesis. J. Nutr. 128:2411-2419.

Mackle, T. R., D. A. Dwyer, K. L. Ingvartsen, P. Y. Chouinard, J. M. Lynch, D. M. Barbano, and D. E. Bauman. 1999. Effects of insulin and amino acids on milk protein concentration and yield from dairy cows. J. Dairy Sci. 82:1512-1524.

McGuire, M. A., J. M. Griinari, D. A. Dwyer, and D. E. Bauman. 1995. Role of insulin in the regulation of mammary synthesis of fat and protein. J. Dairy Sci. 78:816-824.

McMurray, C. H., W. J. Blanchflower, and D. A. Rice. 1984. Automated kinetic method for D-3-hydroxybutyrate in plasma or serum. Clin. Chem. 30:421-425.

Miller, P. S., B. L. Reis, C. C. Calvert, E. J. DePeters, and R. L. Baldwin. 1991. Patterns of nutrient uptake by the mammary glands of lactating dairy cows. J. Dairy Sci. 74:3791-3799.
Oldick, B. S., C. R. Staples, W. W. Thatcher, and P. Gyawu. 1997. Abomasal infusion of glucose and fat effect on digestion, production, and ovarian and uterine functions of cows. J. Dairy Sci. 80:1315-1328.

Palmquist, D. L., A. D. Beaulieu, and D. M. Barbano. 1993. Feed and animal factors influencing milk fat composition. J. Dairy Sci. 76:1753-1771.

Prosser, C. G., S. R. Davis, V. C. Farr, and P. Lacasse. 1996. Regulation of blood flow in the mammary microvasculature. J. Dairy Sci. 79:1184-1197.

Rigout, S., C. Hurtaud, S. Lemosquet, A. Bach, and H. Rulquin. Lactational effect of propionic acid and duodenal glucose in cows. J. Dairy Sci. (accepted).

Rigout, S., S. Lemosquet, J. E. Van Eys, J. W. Blum, and H. Rulquin. 2002a. Duodenal glucose increases glucose fluxes and lactose synthesis in grass silage-fed dairy cows. J. Dairy Sci. 85:595606.

Rulquin, H. 1997. Régulation de la synthèse et de la sécrétion des constituants du lait chez les ruminants. Renc. Rech. Ruminants 4:327-338.

Rulquin, H., P. M. Pisulewski, R. Vérité, and J. Guinard. 1993. Milk production and composition as a function of postruminal lysine and methionine supply: a nutrient-response approach. Livest. Prod. Sci. 37:69-90.

SAS User's Guide: Statistics. Version 6 Edition 4. 1990. SAS Inst., Inc., Cary, NC.

Vernon, R. G. 1981. Lipid metabolism in the adipose tissue of ruminant animals. Pages 280-353 in Lipid Metabolism in Ruminant Animals. W. W. Christie, ed. Pergamon Press, Oxford, England. Vernon, R. G., and M. Peaker. 1983. The regulation of nutrient utilization: basic principles and mechanisms. Pages 41-113 in Nutritional Physiology of Farm Animals. J. A. F. Rook, ed. Longman Corp. Ltd, London, England. 